\title{
ANALISIS TIPOLOGI URBAN SPRAWL DI KOTA BANDUNG MENGGUNAKAN SISTEM INFORMASI GEOGRAFIS
}

\author{
(Urban sprawl Typology Analysis in Bandung City using Geographic Information System)
}

\section{Millary Agung Widiawaty, Moh. Dede, dan Arif Ismail}

Universitas Pendidikan Indonesia

Jalan Dr. Setiabudhi no. 229, Kel. Isola, Kec. Sukasari, Kota Bandung, Jawa Barat, Indonesia (40154)

E-mail: millary@student.upi.edu

\begin{abstract}
ABSTRAK
Fenomena urban spraw/ terjadi akibat laju urbanisasi yang tinggi di kawasan perkotaan. Urban sprawl menyebabkan pesatnya pertumbuhan penggunaan lahan perkotaan yang dicirikan oleh lahan terbangun, sehingga alih fungsi lahan menuju wilayah pinggiran kota menjadi tidak terkendali. Salah satu wilayah perkotaan yang memiliki laju alih fungsi lahan tertinggi di Indonesia adalah Kota Bandung. Penelitian ini bertujuan untuk mengetahui tipologi urban spraw/ di Kota Bandung yang meliputi analisis identifikasi, karakteristik, serta klasifikasi fenomena tersebut. Klasifikasi tingkat urban spraw/ akan menunjukkan tipologi spraw/ yang terbagi atas tipologi satu (rendah), tipologi dua (sedang), dan tipologi tiga (tinggi) sebagai hasil pengharkatan dan overlay semua parameter menggunakan perangkat lunak SIG. Hasil penelitian ini menunjukkan pada tahun 2005, urban spraw/ tipologi satu terjadi pada 8 (delapan) kecamatan, tipologi dua pada 4 (empat) kecamatan, dan tipologi tiga meliputi 2 (dua) kecamatan. Pada tahun 2018, kecamatan yang tergolong tipologi satu berubah menjadi 7 (tujuh) kecamatan, tipologi dua meliputi 10 kecamatan, dan tipologi tiga terdiri atas 11 kecamatan. Selama kurun waktu 13 tahun, kecenderungan urban spraw/ meningkat ke bagian timur Kota Bandung, karena memiliki kondisi geografis yang datar dan terdapat CBD Jatinangor. Fenomena urban spraw/ seharusnya dapat diperhatikan secara bijak oleh pemerintah dengan melakukan pengawasan terhadap perkembangan kota, seperti penerapan konsep compact city.
\end{abstract}

Kata kunci: Kota Bandung, SIG, urban sprawl

\section{ABSTRACT}

The phenomenon of urban sprawl occurs due to high rate of urbanization in urban region. Urban sprawl causes the rapid growth of urban land use which is characterized by built-up land and pull the conversion of land to suburban areas become uncontrolled. Urban area with the highest rate of land conversion in Indonesia is Bandung. This study aims to determine urban sprawl typology in Bandung City which includes identification, characteristics, and classification analysis of the phenomenon. The classification level of urban spraw/ shows the sprawl typology is divided into typology one (low), typology two (moderate) and typology three (high). It obtained from the scoring and overlay all parameters using GIS software. The results indicate that in 2005 urban sprawl type one has occurred in 8 (eight) sub-districts, typology two in 4 (four) sub-districts, and typology three happen in 2 (two) sub-districts. In 2018, sub-districts are classified as typology one changed to 7 (seven) sub-districts, typology two covered 10 sub-districts, and typology three consisted of 11 subdistricts. During 13 years, urban sprawl tend to increase toward the eastern of Bandung which had suitable geographical conditions and supported by CBD Jatinangor. Urban sprawl should be studied wisely by the government to monitoring the development and application a compact city concept.

Keywords: Bandung City, GIS, urban sprawl

\section{PENDAHULUAN}

Urban spraw/menjadi tantangan utama dalam perencanaan tata ruang di perkotaan. Fenomena tersebut menyebabkan pesatnya pertumbuhan penggunaan lahan perkotaan yang dicirikan oleh lahan terbangun yang menyebabkan tidak terkendalinya alih fungsi lahan menuju wilayah pinggiran kota (Owoeye \& Opoola, 2016). Urban spraw/merupakan bentuk perkembangan kota yang dapat ditinjau dari meningkatnya jumlah bangunan, tempat parkir, dan berbagai fasilitas umum. Urban spraw/ juga dapat diamati dari perubahan gaya hidup masyarakat perkotaan dari segi transportrasi yakni meningkatnya angka ketergantungan pada penggunaan kendaraan bermotor bahkan menjadi satu-satunya pilihan untuk melakukan perjalanan, sehingga menimbulkan efek ketergantungan yang akut (Ramelia \& Setyono, 2015). Dalam jangka panjang urban spraw/ dapat menimbulkan masalah 
yang lebih kompleks yakni menurunnya kualitas air serta meningkatnya polusi udara akibat transportasi dan pembangunan industri (Ardiwijaya, 2014; Pereira, Monkevičius \& Siarova, 2014). Selain itu, urban spraw/ juga dapat dicirikan dari pola tata guna lahan tunggal (single-use zoning) berupa lahan terbangun (Solecka, Sylla \& Świąder, 2017).

Urban spraw/ umumnya mengarah pada wilayah yang memiliki aksesibilitas tinggi serta mudah untuk dilakukan pengembangan lahan menjadi lahan terbangun guna menunjang urbanitas masyarakat (Dubey \& Kumar, 2013). Laju urban sprawl juga akan semakin pesat bila angka pertumbuhan dan pertambahan penduduk yang tinggi, sehingga pemenuhan kebutuhan terhadap lahan akan dilakukan pada area yang memiliki kepadatan penduduk yang lebih rendah terutama kawasan sub-urban di sekitarnya (Jain \& Dimri, 2016). Bila tidak terkelola dengan baik, urban spraw/ dapat menyebabkan degradasi lingkungan dan meningkatkan segregasi dan merusak vitalitas daerah perkotaan yang ada dan menyerang dengan alasan estetik (James et. al., 2013). Fenomena urban spraw/ umumnya terjadi pada kota-kota besar yang memiliki laju konversi lahan yang tinggi (Mujiandari, 2014). Salah satu wilayah perkotaan yang memiliki laju alih fungsi lahan tertinggi di Indonesia adalah Kota Bandung. Setiap tahunnya rata-rata laju konversi lahan tidak terbangun menjadi lahan terbangun mencapai 137 ha (Pusat Data dan Informasi Kementerian Pertanian, 2015). Fenomena urban spraw/di Kota Bandung terjadi akibat pertambahan jumlah penduduk, baik karena pertumbuhan alami maupun akibat mobilitas penduduk akibat urbanisasi yang tinggi, serta meningkatnya kebutuhan akan lahan terbangun untuk menunjang berbagai aktivitas.

Pengamatan terhadap urban spraw/ dapat dilakukan dengan analisis tipologi perkotaan yang meliputi tahap identifikasi, analisis karakteristik, dan klasifikasi sprawl (Apriani dan Asnawi, 2015). Oleh sebab itu, penelitian ini memiliki tujuan untuk mengetahui tipologi urban spraw/ di Kota Bandung yang meliputi 1) analisis identifikasi untuk sebagai tahap awal penyeleksian wilayah; 2) analisis karakteristik yang meliputi analisis kepadatan penduduk, bangunan, dan jarak terhadap $\mathrm{CBD} ; 3$ ) serta pengklasifikasiannya. Klasifikasi tingkat urban spraw/ di Kota Bandung terbagi atas tipologi 1 (rendah), tipologi 2 (sedang), dan tipologi 3 (tinggi).

\section{METODE}

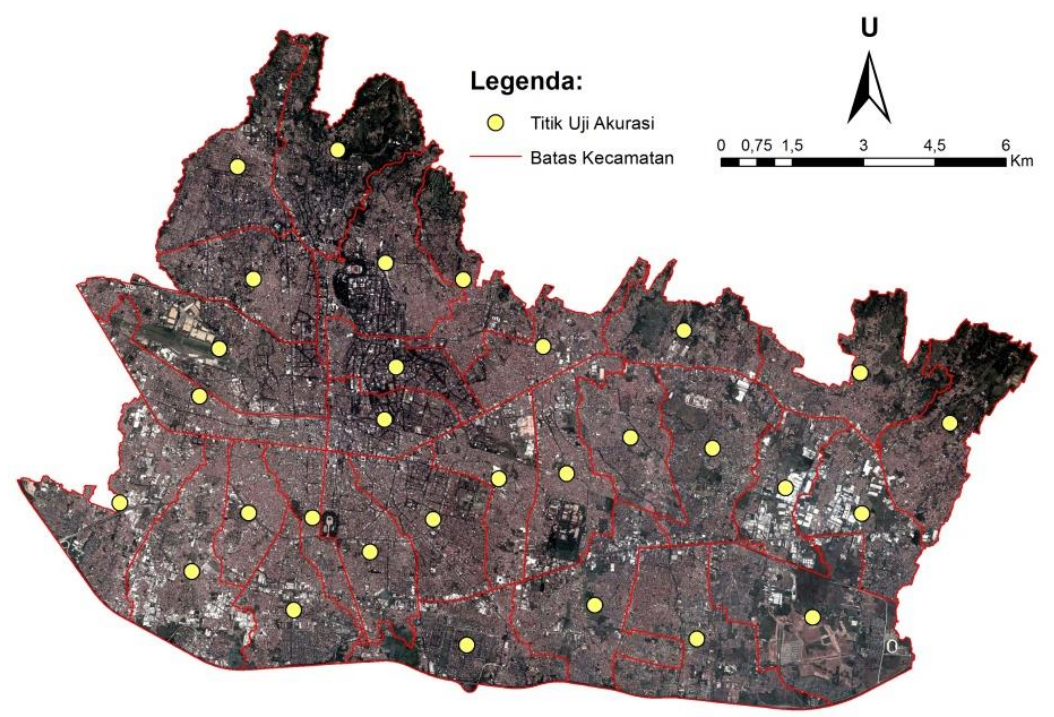

Gambar 1. Sebaran sampel pengamatan berbasis sentroid kecamatan untuk uji akurasi lahan terbangun dan non terbangun.

Analisis urban spraw/ di Kota Bandung memerlukan data jumlah rumah tangga (keluarga), rasio lahan terbangun dan tidak terbangun, kepadatan penduduk, kepadatan bangunan, serta jarak suatu wilayah terhadap central bussiness district (CBD), data penelitian dapat dilihat pada Tabel 1. Data mengenai lahan secara khusus diperoleh melalui analisis penginderaan jauh menggunakan citra Landsat-5 TM tahun 2005 dan citra Sentinel-2 tahun 2018 yang diunduh melalui laman Earth Expolrer USGS. Dalam penelitian ini, analisis penginderaan jauh dan sistem informasi geografis (SIG) dilakukan menggunakan perangkat lunak Erdas ER Mapper, QGIS Las Palmas, dan Google Earth Pro. 
Tabel 1. Akuisisi data penelitian.

\begin{tabular}{|c|c|c|c|c|c|}
\hline Data & \multicolumn{3}{|c|}{ Sumber Data } & Tipe Data & Tahun \\
\hline Luas wilayah & Sekunder & BIG & AOI Tanahair & Vektor & 2018 \\
\hline $\begin{array}{l}\text { Jumlah } \\
\text { rumah } \\
\text { tangga }\end{array}$ & Sekunder & $\begin{array}{l}\text { BPS Kota } \\
\text { Bandung }\end{array}$ & $\begin{array}{l}\text { Kota Bandung } \\
\text { dalam Angka }\end{array}$ & Atribut & 2017 \\
\hline $\begin{array}{l}\text { Lahan } \\
\text { terbangun } \\
\text { dan tidak } \\
\text { terbangun }\end{array}$ & Sekunder & $\begin{array}{c}\text { USGS } \\
\text { Digital Globe }\end{array}$ & $\begin{array}{c}\text { Citra Sentinel-2 } \\
\text { Citra Landsat-5 TM } \\
\text { Citra CNES } \\
\text { Astrium / Airbus }\end{array}$ & $\begin{array}{l}\text { Raster } \\
\text { Raster }\end{array}$ & $\begin{array}{l}2018 \\
2005\end{array}$ \\
\hline $\begin{array}{l}\text { Kepadatan } \\
\text { penduduk }\end{array}$ & Sekunder & $\begin{array}{l}\text { BPS Kota } \\
\text { Bandung }\end{array}$ & $\begin{array}{l}\text { Kota Bandung } \\
\text { dalam Angka }\end{array}$ & Atribut & $\begin{array}{l}2018 \\
2005\end{array}$ \\
\hline $\begin{array}{l}\text { Kepadatan } \\
\text { bangunan }\end{array}$ & Sekunder & $\begin{array}{l}\text { BPS Kota } \\
\text { Bandung }\end{array}$ & $\begin{array}{c}\text { Kota Bandung } \\
\text { dalam Angka }\end{array}$ & Atribut & $\begin{array}{l}2018 \\
2005\end{array}$ \\
\hline $\begin{array}{c}\text { Jarak } \\
\text { terhadap } \\
\text { CBD }\end{array}$ & Primer & $\begin{array}{l}\text { Buffering } \\
\text { dengan GIS } \\
\text { software }\end{array}$ & $\begin{array}{l}\text { Dekat } 0-5 \mathrm{~km} \\
\text { Jauh }>5-10 \mathrm{~km}\end{array}$ & Vektor & 2018 \\
\hline
\end{tabular}

Citra tersebut diolah berdasarkan klasifikasi tidak terselia (unsupervised classification), data pembandingnya berupa citra resolusi tinggi CNES Astrium / Airbus dengan melibatkan 30 sampel untuk masing-masing sentroid kecamatan (lihat Gambar 1). Menurut Al-doski, Mansor, \& Shafri (2013), data pembanding dalam unsupervised classification dapat dilakukan dengan tiga cara yakni pengecekan lapangan, membandingkan dengan peta yang sudah valid, dan membandingkan dengan citra lain yang memiliki resolusi tinggi atau sangat tinggi. Analisis lahan terbangun dan tidak terbangun menunjukkan overall accuracy mencapai 86,67 persen (tahun 2018) dan 83,3 persen (tahun 2005), sehingga data lahan yang diperoleh dari citra tersebut dinyatakan layak.

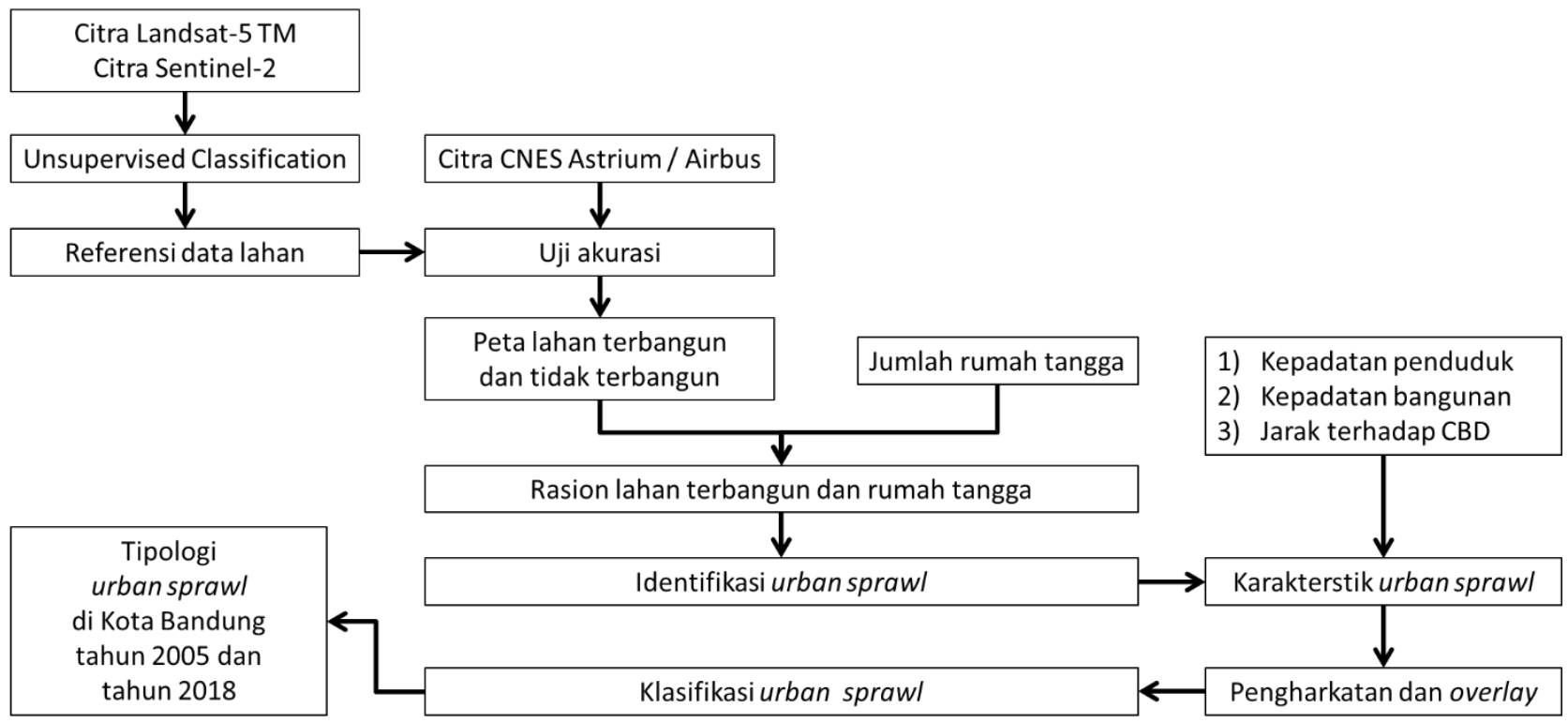

Gambar 2. Alur penelitian urban sprawl.

Penentuan urban spraw/dilakukan melalui tiga tahap. 1) tahap identifikasi wilayah urban spraw/ dilakukan untuk mengetahui rasio rumah tangga dan rasio antara lahan terbangun, urban sprawl terjadi bilai nilai rasio lahan terbangun lebih besar dari pada nilai rasio rumah tangga dan vice versa, tetapi bila antara kedua parameter tersebut (nol) maka suatu wilayah dinyatakan compact. 2) tahap analisis karakteristik, pengukuran spraw/pada wilayah yang telah teridentifikasi melibatkan 3 (tiga) parameter yakni kepadatan penduduk, kepadatan bangunan, dan jarak kecamatan ke pusat kegiatan (CBD). 3) tahap klasifikasi urban sprawl bertujuan untuk menggolongkan wilayah yang mengalami urban spraw/ dengan tipologi 1 (rendah), tipologi 2 (sedang), dan tipologi 3 (tinggi), klasifikasi diperoleh dari proses pengharkatan dan overlay semua parameter. Selengkapnya mengenai alur 
penelitian urban spraw/ di Kota Bandung tersaji pada Gambar 2, sedangkan acuan skor untuk proses pengharkatan mengacu pada tabel 2 sebagai berikut.

Tabel 2. Skor untuk tiap parameter karakteristik urban sprawl.

\begin{tabular}{cccccc}
\hline \multirow{2}{*}{ Skor } & \multicolumn{2}{c}{2005} & \multicolumn{2}{c}{$\mathbf{2 0 1 8}$} & \multirow{2}{*}{ Jarak terhadap CBD } \\
\cline { 2 - 5 } & $\begin{array}{c}\text { Kepadatan } \\
\text { Penduduk }\end{array}$ & $\begin{array}{c}\text { Kepadatan } \\
\text { Bangunan }\end{array}$ & $\begin{array}{c}\text { Kepadatan } \\
\text { Penduduk }\end{array}$ & $\begin{array}{c}\text { Kepadatan } \\
\text { Bangunan }\end{array}$ & \\
\hline 3 & $18-49$ & $1,77-2,51$ & $49,62-166,51$ & $2,19-3,14$ & - \\
2 & $49-130$ & $2,52-3,14$ & $166,52-249,63$ & $3,15-3,76$ & Jauh \\
1 & $130-236$ & $3,15-4,45$ & $249,64-637,72$ & $3,77-5,77$ & Dekat \\
\hline
\end{tabular}

\section{HASIL DAN PEMBAHASAN}

\section{Identifikasi Urban Sprawl}

Pada tahun 2005, sebanyak 14 kecamatan di Kota Bandung teridentifikasi mengalami urban sprawl yang diperoleh dari hasil pengurangan antara jumlah rumah tangga dan rasio lahan terbangun yang bernilai negatif, sedangkan sebanyak 16 kecamatan terindikasi compact karena memiliki nilai nol. Kondisi berbeda terjadi pada tahun 2018, dimana terdapat 28 kecamatan yang teridentifikasi urban spraw/ dan satu kecamatan yang teridentifikasi compact. Di tahun ini pula, teridentifikasi satu kecamatan yang berperan sebagai CBD bagi Kota Bandung, karena memiliki nilai rasio yang positif (lihat Gambar $\mathbf{3}$ ).

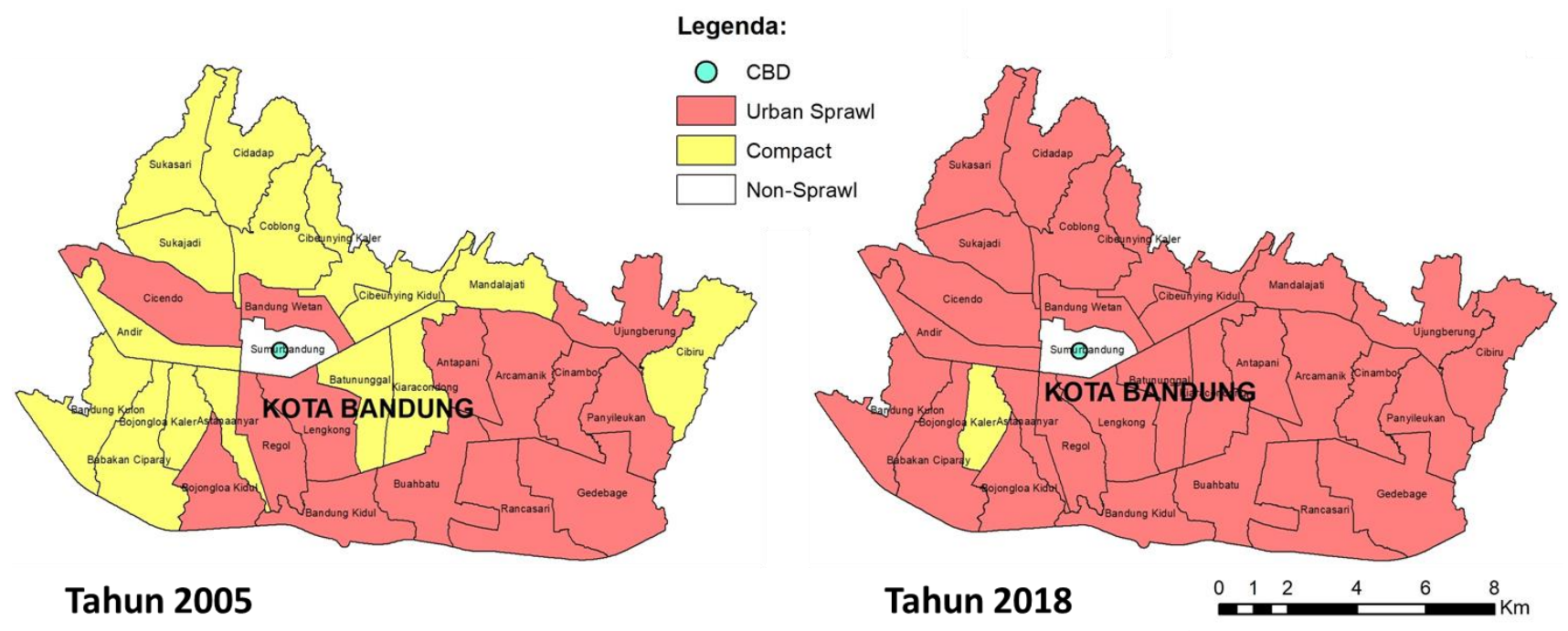

Gambar 3. Perbadingan hasil identifikasi urban spraw/ di Kota Bandung tahun 2005 dan 2018.

Analisis identifikasi hanya menunjukkan proses perkembangan keruangan di suatu suatu wilayah perkotaan, sehingga hasilnya tidak menunjukkan ukuran yang mutlak. Oleh sebab itu, analisis identifikasi hanya digunakan untuk menentukan wilayah yang mengalami urban sprawl. Meskipun hasil ini merupakan basis untuk analisis lanjutan guna menentukan tipologi urban sprawl.

\section{Karakteristik Urban SprawI}

\section{Kepadatan Penduduk}

Analisis kepadatan penduduk dilakukan dengan menggunakan data jumlah penduduk yang dibagi dengan luas lahan terbangun pada tiap kecamatan di Kota Bandung. Pada tahun 2005 diketahui bahwa Kecamatan Bandung Kidul merupakan wilayah dengan kepadatan penduduk terendah (18,13 jiwa/ha), sedangkan kepadatan penduduk tertinggi dimiliki oleh Kecamatan Regol dengan (236,108 jiwa/ha). Sementara itu, pada tahun 2018 terjadi perubahan yang mana Kecamatan Gedebage merupakan wilayah dengan kepadatan penduduk terendah $(49,618$ jiwa/ha) dan Kecamatan Astanaanyar didaulat sebagai wilayah yang memiliki kepadatan penduduk tertinggi 
(350,969 jiwa/ha). Secara detail, dinamika fenomena kepadatan penduduk di Kota Bandung tersaji pada Gambar 4.

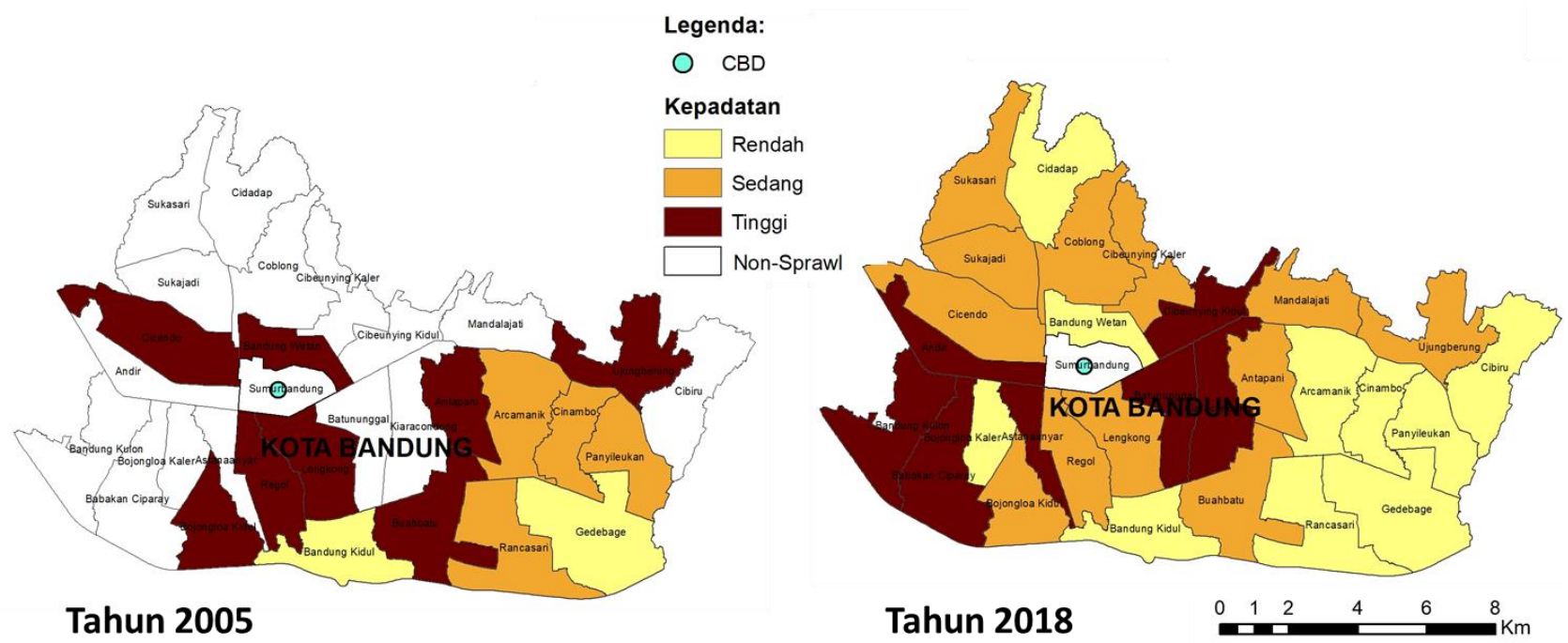

Gambar 4. Perbandingan kepadatan bangunan di Kota Bandung selama 13 tahun.

Wilayah yang padat penduduk mengindikasikan tingkat urban spraw/yang rendah, sedangkan kondisi sebaliknya menunjukkan rendahnya tingkat urban sprawl. Ketersediaan ruang dan lahan pada wilayah yang rendah kepadatan penduduknya memicu masyarakat, pemerintah, hingga pengembang untuk melakukan ekspansi perkotaan menuju wilayah bersangkutan. Dinamika selama 13 tahun di Kota Bandung membuktian hal tersebut, dimana wilayah yang sebelumnya memiliki kepadatan penduduk tinggi berubah menjadi lebih rendah dan kondisi ini berlaku sebaliknya.

\section{Kepadatan Bangunan}

Kepadatan bangunan dalam analisis urban spraw/ dilakukan menghitung rasio antara jumlah unit bangunan dengan luas lahan terbangun. Di tahun 2005, Kota Bandung memiiki kepadatan bangunan sebesar 3,1 unit/ha. Selama 13 tahun, kepadatan bangunan di wilayah ini mengalami peningkatan menjadi 4,0 unit/ha. Serupa dengan kepadatan penduduk yang telah dibahas sebelumnya, kepadatatan bangunan yang rendah di suatu wilayah mengindikasikan tingkat urban sprawl yang rendah yang disebabkan ekspansi area untuk lahan terbangun dan bangunan yang makin terbatas, kondisi ini disebut pula sebagai leaffrog effect.

Berdasarkan Gambar 5 diketahui adanya peningkatan jumlah wilayah yang memiliki kepadatan bangunan level sedang dan tinggi. Peningkatan tersebut terjadi secara masif menuju wilayah selatan dan timur Kota Bandung seperti yang dialami oleh Kecamatan Panyileukan dan Bojongloa Kaler, dimana pada tahun 2005 dideteksi sebagai wilayah dengan kepadatan penduduk yang rendah dan menandakan leaffrog effect terjadi secara nyata.

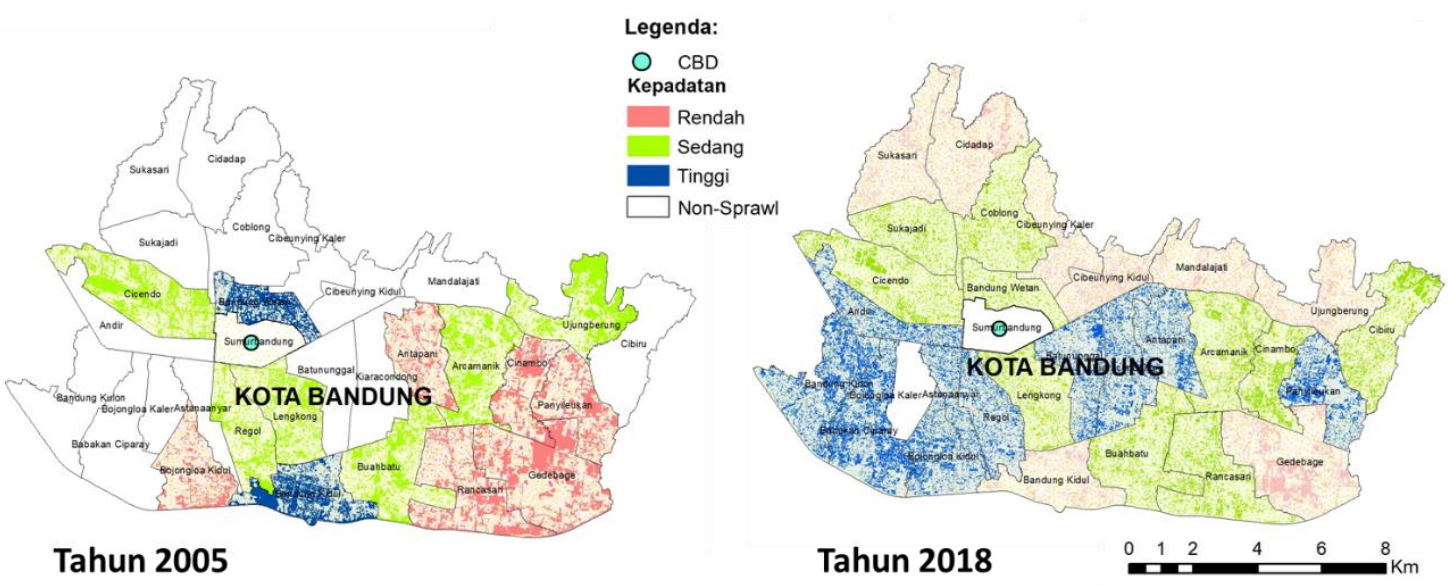

Gambar 5. Perbandingan Kepadatan Penduduk di Kota Bandung selama 13 tahun. 
Jarak terhadap CBD

Analisis jarak ke pusat kegiatan perkotaan dilakukan dengan mengukur jarak CBD Kota Bandung (Sumur Bandung), CBD Kota Cimahi, dan CBD Bagian Barat Kabupaten Sumedang (Jatinangor) terhadap wilayah yang teridentifikasi mengalami urban spraw/melalui buffering sejauh 5 (lima) km dan 10 (sepuluh) km. Semakin dekat jarak suatu wilayah terhadap CBD akan mengindikasikan tingkat urban spraw/ yang rendah dan berlaku sebaliknya. Di Kota Bandung, seluas 50,3 persen wilayahnya berada pada jangkauan CBD hingga jarak 5 (lima) km (lihat Gambar 6).

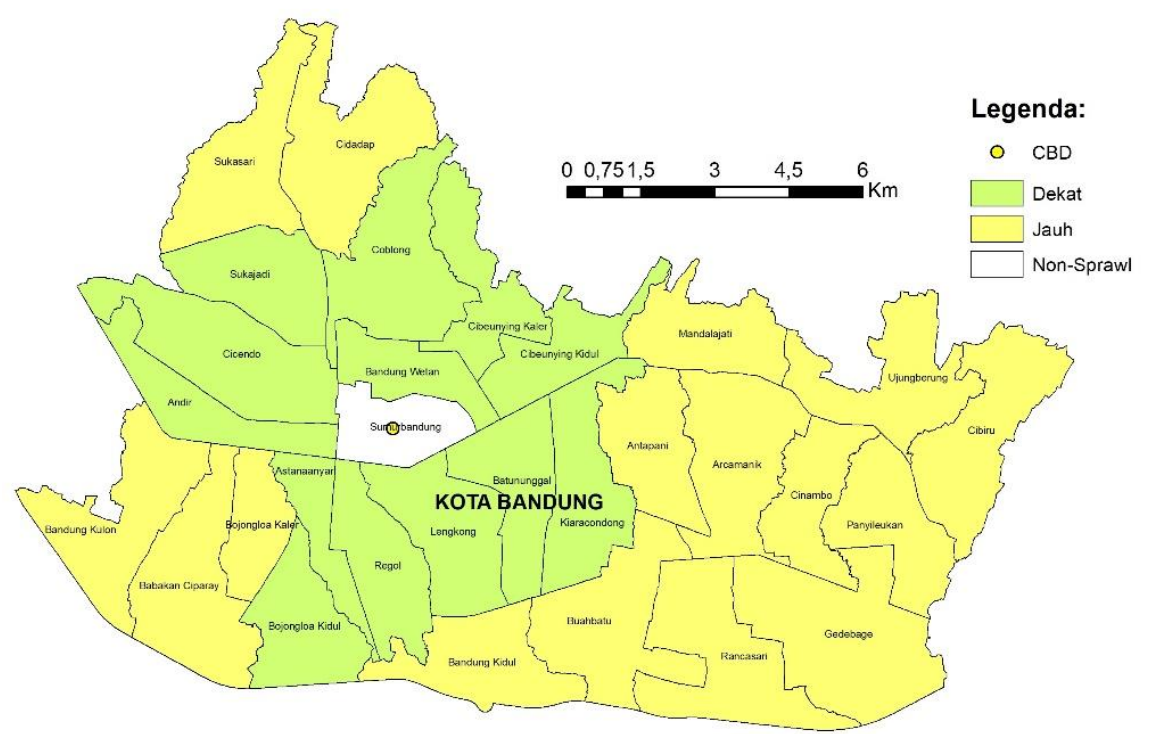

Gambar 6. Jarak terhadap CBD untuk masing-masing kecamatan di Kota Bandung.

Wilayah kecamatan yang memiliki jangkauan dekat terhadap CBD berada di bagian barat Kota Bandung. Wilayah tersebut sering dipersepsikan oleh masyarakat Bandung sebagai daerah pusat kota yang meliputi 14 kecamatan karena berada pada radius 5 (lima) km, bahkan berbagai masalah klasik perkotaan pun seperti slum area dan kerawanan kejahatan dapat dengan mudah ditemukan di wilayah ini (Dede, Setiawan, \& Mulyadi, 2017).

Di bagian timur Kota Bandung, tidak ditemukan adanya wilayah yang berada pada jangkauan 5 (lima) km terhadap CBD Jatinangor maupun CBD Kota Bandung, meskipun ditemukan adanya sedikit pengaruh dari CBD Jatinangor di Kecamatan Cibiru. Oleh sebab itu, wilayah di bagian timur Kota Bandung cocok bila dikembangkan berdasarkan konsep new development atau kota baru seperti yang digagas oleh pengembang Summarecon Agung.

\section{Tipologi Urban Sprawl di Kota Bandung}

Pada tahun 2005, seluas 46,67 persen wilayah Kota Bandung mengalami urban spraw/ dengan beragam tipologinya yang terbagi atas tipolgi 1 (satu) pada 8 (delapan) kecamatan (26,67 persen), tipologi 2 (dua) pada 4 (empat) kecamatan (13,33 persen), dan tipologi 3 (tiga) pada 2 (dua) kecamatan (6,67 persen). Di tahun tersebut, urban spraw/ di Kota Bandung mengarah pada bagian timur dan selatan. Selama kurun waktu 13 tahun, wilayah yang mengalami urban spraw/ di Kota Bandung meningkat secara signifikan (lihat Gambar 7). Di tahun 2018, hampir seluruh wilayah ini (93,33 persen) mengalami urban spraw/ yang terbagi atas tipologi 1 (satu) sebanyak 7 (tujuh) kecamatan, tipologi 2 (dua) sebanyak 10 (sepuluh) kecamatan, dan tipologi 3 (tiga) sebanyak 11 (sebelas) kecamatan. 


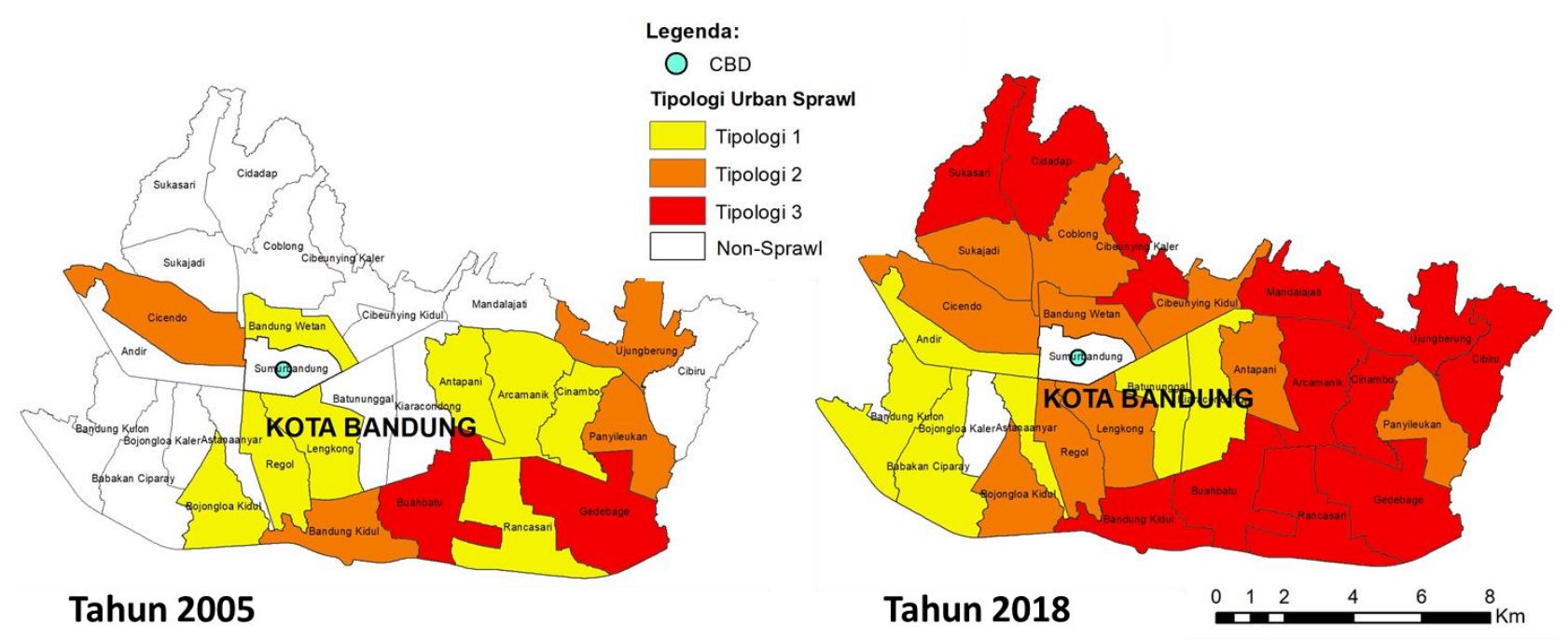

Gambar 7. Perbandingan urban spraw/pada tahun 2005 dan 2018.

Pada tahun 2018, urban spraw/ level tertinggi (tipologi 3) berkembang secara pesat dengan pola memusat ( $p$-value 0,04 dan $z$-score 2,02 ) menuju bagian timur Kota Bandung yang secara geografis memiliki topografi yang relatif datar, rendah risiko terhadap pergerakan tanah, dan lahan yang cukup tersedia, sehingga berpotensi menjadi lahan fisik perkotaan dapat berkembang dengan baik. Kondisi jauh berbeda dengan keadaan urban spraw/pada tahun 2005 yang memiliki pola acak ( $p$-value 0,53 dan $z$-score 0,61). Selain itu, daya tarik masyarakat untuk menciptakan lahan terbangun juga didukung oleh lokasi wilayah tersebut yang relatif dekat dengan CBD Jatinangor.

Laju urban spraw/menuju bagian timur Kota Bandung juga didukung oleh kebijakan pemerintah yang mendorong terbentuknya pusat-pusat pertumbuhan baru di luar CBD eksisting, meskipun hal ini akan mendorong perubahan sosial-budaya masyarakat yang sebelumnya berorientasi pada sektor pertanian menuju sektor jasa dan industri perkotaan. Di sisi lain, fenomena urban sprawl juga dikhawatirkan akan menyebabkan laju alih fungsi lahan pertanian produktif menjadi sangat pesat yang dicirikan oleh sikap masyarakat untuk mudah menjual lahan kepada pihak pengembang karena menilai harga jual lahan yang relatif tinggi (Ajikusumah, 2017; Kusumadewi, 2016).

\section{KESIMPULAN}

Peningkatan urban spraw/ di Kota Bandung dari tahun 2005 hingga 2018 mencapai 115,38 persen, gejala penurunan jumlah hanya terjadi pada wilayah tipologi 1 mencapai -14,29 persen yang disebabkan oleh adanya perubahan beberapa wilayah tipologi ini ke tingkat tipologi urban spraw/ yang lebih tinggi seperti dialami oleh Kecamatan Bandung Wetan dan Kecamatan Bojongloa Kidul. Secara umum, lonjakan urban spraw/ meningkat pesat dan memusat di bagian timur Kota Bandung baik dari segi jumlah maupun tipologinya. Peningkatan ini menandakan perkembangan Kota Bandung terus berlangsung hingga ke wilayah sub-urban di sekitarnya. Oleh sebab itu, guna menanggulangi berbagai dampak negatif akibat urban sprawl di Kota Bandung, kegiatan pengawasan terhadap perkembangan kota seperti penerapan konsep compact city, analisis laju alih fungsi lahan, dan pengetatan izin mendirikan bangunan perlu direalisasikan secara bijak.

\section{UCAPAN TERIMA KASIH}

Terima kasih penulis ucapkan kepada Prof. Dr. Enok Maryani yang telah memacu dan membimbing penulis untuk menganalisis fenomena spasial-temporal kawasan perkotaan. Tak lupa pula kepada pihak FPIPS (khususnya kepada Dr. Siti Nurbayani selaku Wakil Dekan Bidang Kemahasiswaan) dan rektorat UPI yang turut serta mendukung kegiatan publikasi ilmiah. 


\section{DAFTAR PUSTAKA}

Ajikusumah, D. (2017). Kajian tentang Pembangunan Teknopolis dalam Perspektif Keberlanjutan Warga Pinggiran Kota (Studi Kasus: Warga Kampung Rancabayawak Gedebage Kota Bandung). Tesis Program Studi Magister Studi Pembangunan Institut Teknologi Bandung. Bandung.

Al-doski, J., S. B. Mansor, and H. Z. M. Shafri. (2013). Image Classification in Remote Sensing. Journal of Environment and Earth Science, 3 (10), 141 - 147.

Apriani, V. I., \& Asnawi. (2015). Tipologi Tingkat Urban Sprawl di Kota Semarang Bagian Selatan. Jurnal Teknik $P W K, 4(3), 405-416$.

Ardiwijaya, V. S., dkk. (2014). Bandung Urban spraw/ and Idle Land: Spatial Environmental Perspectives. Jurnal Precedia, 10, $208-213$.

Dede, M., I. Setiawan and A. Mulyadi. (2017). Application GIS to Analyse Crime Risk in Bandung. An Article in The $2^{\text {nd }}$ UPI International Conference of Sociology Education, 4 October 2017. Bandung.

Dubey, P. and D. Kumar, D. (2013). Urban sprawl and its Impact on Urban Environment. IOSR Journal of Mechanical and Civil Engineering (IOSR-JMCE), 9 (5), $26-31$.

Jain, M \& A. P. Dimri. (2016). Urban spraw/ Patterns and Processes in Delhi from 1977 to 2014 Based on Remote Sensing and Spatial Metrics Approaches. Earth Interactions Journal, 2, 1 - 29.

James, P. M., M., et. al. (2013). Managing Metropolises by Negotiating Mega-Urban Growth. In H. Mieg \& Klaus Töpfer (eds.). Institutional and Social Innovation for Sustainable Urban Development. Routledge. London

Mujiandari, R. (2014). Perkembangan Urban spraw/ Kota Semarang pada Wilayah Kabupaten Demak Tahun 2001-2012. Jurnal Wilayah dan Lingkungan, 2 (2), 129 - 142.

Owoeye, J. 0 \& O. O. Opoola. (2016). Predicting Urban spraw/ and Land Use Changes in Akure Region using Markov Chains Modeling. Journal of Geography and Regional Planning, 10 (7), 197 - 207.

Pereira, P., A. Monkevičius and H. Siarova. (2014). Public Perception of Environmental, Social and Economic Impacts ff Urban sprawl In Vilnius. Societal Studies Journal, 6 (2), 259 - 290.

Pusat Data dan Informasi Kementerian Pertanian. (2015). Statistika Lahan Pertanian Tahun 2010-2014. Sekretariat Jenderal Kementerian Pertanian. Jakarta.

Ramelia, P. \& J. S. Setyono. (2015). Ketergantungan terhadap Kendaraan Pribadi di Kota Pontianak Kalimantan Barat. Jurnal Teknik PWK, 4 (1), 107 - 118.

Solecka, I., M. Sylla and M. Świąder. (2017). Urban Spraw/Impact on Farmland Conversion in Suburban Area of Wroclaw, Poland. IOP Conf. Series: Materials Science and Engineering, 245. 